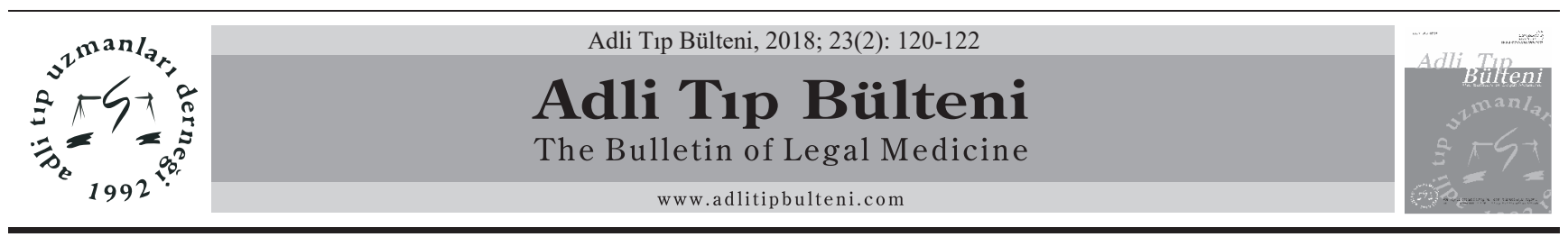

\title{
Baby Death due to Esophagotracheal Fistula Created by An Alkaline Battery: A Case Report
}

\author{
Alkalin Pil ile Oluşan Özofagus Fistülüne Bağlı Bebek Ölümü: Bir Olgu Sunumu \\ Hacer Yaşar Teke ${ }^{1}$, Muhammet Can², Tülay Renklidă̆ ${ }^{3}$, Nevriye Temel $^{3}$, Asude Gökmen ${ }^{3}$ \\ ${ }^{1}$ Ordu University Faculty of Medicine, Department of Forensic Medicine, Ordu \\ ${ }^{2}$ Balıkesir University Faculty of Medicine, Department of Forensic Medicine, Balıkesir \\ ${ }^{3}$ The Council of Forensic Medicine, Ankara Group Chairmanship, Ankara
}

\begin{abstract}
There is a limited number of case presentations in literature related to esophagus burns and complications as a result of swallowing an alkaline battery. The main purpose of this case presentation was to discuss the autopsy findings of late-developing complications of swallowing an alkali battery in the light of the relevant literature.

On the chest radiography of a 9-month old baby with complaints of vomiting for three days, an opacity was observed consistent with a foreign body in the esophagus. Esophagoscopy was applied and the swallowed battery was removed. On the fifth day after the operation, no complication has been observed to oral feeding was started and on the following day the patient was discharged. Four days after discharge, the patient was again brought to hospital with complaints of blood in vomit and was again hospitalized with a diagnosis of chemical esophageal burn. The patient died on the following day. In the performed autopsy, findings of esophagotracheal fistula, corrosive burn and gastrointestinal system bleeding were determined.

As the dimensions of an alkaline battery increase, the contact surface increases and may this cause greater damage and toxicity. A long contact period also increases the toxic effect of the battery. Early diagnosis is essential to prevent late-developing complications.

Keywords: Alkaline Battery; Esophagotracheal Fistula; Autopsy; Forensic Medicine.
\end{abstract}

\section{Özet}

Alkali pil yutma sonucu meydana gelen özofagus yanıkları ile oluşan komplikasyonlar ile ilgili literatürde, sınırlı sayıda vaka sunumu bulunmaktadır. Bu olgu sunumunun temel amac1, bir alkali pil yutulması olayı sonrası geç gelişen komplikasyon bulgularına ait otopsi bilgisinin ilgili literatür 1şı̆̆gnda tartışı1masidir.

Üç aydır kusma yakınması olan 9 aylık erkek bebeğin göğüs radyografisinde özofagusta yabancı cisim ile uyumlu olarak bir opasite gözlendi. Bebeğe, özofagoskopi uygulanarak yutulan pil çıkarıldı. Operasyondan sonraki beşinci gün oral beslenmeye başlanıldığında herhangi bir komplikasyon gözlenmedi ve ertesi gün taburcu edildi. Taburcu olduktan dört gün sonra tekrar kusma şikayetleri ile hastaneye getirildi ve tekrar kimyasal özofageal yanık tanısı ile hastaneye yatırıldı. Hasta ertesi gün öldü. Yapılan otopside özofagotrakeal fistül bulguları, korozif yanma ve gastrointestinal sistem kanaması tespit edildi.

Bir alkali pilin boyutları arttıkça, temas yüzeyi artar ve bu nedenle daha büyük zarara ve toksisiteye neden olabilir. Uzun temas süresi pilin zehirli etkisini de arttırır. Erken teşhis geç gelişen komplikasyonları önlemek için şarttır.

Anahtar Kelimeler: Alkalin Pil, Özofagus Fistülü, Otopsi, Adli Tip.

\section{Introduction}

Alkaline batteries have become the second most swallowed foreign bodies following coins. Most cases have an uncomplicated course, but some may lead to serious complications and even death (1). Foreign substance aspirations are mostly reported in the 1-3-year age group

Corresponding Author: Assoc. Prof. Dr. Muhammet Can

Balıkesir University Faculty of Medicine, Department of Forensic Medicine, Balıkesir

E-mail: balikesircan@gmail.com

Received:11.12.2017 Revised:12.02.2018 Accepted:02.05.2018
(2). Esophagus foreign substances are mostly monitored in childhood $(3,4)$. It is possible that $20 \%$ of the cases can be asymptomatic and it is also possible that symptoms imitating respiratory tract infections may cause esophagus foreign substance cases to be missed and so such foreign substances may stay for a long period of time in the esophagus (4). Despite alkaline batteries constituting less than $2 \%$ of all foreign substances swallowed by children, in recent years they have been reported to be the second most common objects after metal coins (5). Alkaline batteries larger than $20 \mathrm{~mm}$ cause serious esophageal damage, which may be the result of electricity leakage, 
pressure necrosis, mercury toxicity or the forming of an alkaline medium. Concentrated potassium hydroxide release forms a corrosive effect, from which mediastinitis or esophagotracheal fistula may be formed $(6,7)$. There are very few case presentations in literature related with esophagus burns and complications as a result of swallowing an alkaline battery (8-10).

The main purpose of this paper was to evaluate in the light of relevant literature, the autopsy findings of late complications of swallowing an alkaline battery.

\section{Case Report}

Examination of the 9-month old boy who was brought to the hospital with the complaint of vomiting ongoing for 3 days only showed the tonsils to be hypertrophic and hyperemic and both cheeks hyperemic and dry. Chest radiography revealed an opacity consistent with a foreign body

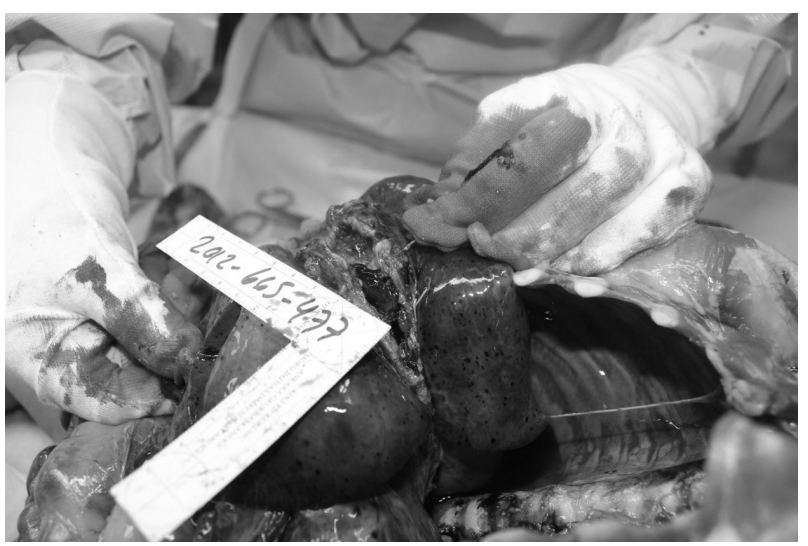

Fig 1. During the autopsy alkaline battery corrosive burn was detected in the esophagus. in the esophagus. The foreign body, a swallowed battery was removed following the esophagoscopy. On the fifth postoperative day, no complications had been observed so oral feeding was started. No problem was observed in the swallowing functions. The patent was discharged on the 6th day of hospitalization. Four days after, the infant was again hospitalized due to vomiting blood and chemical esophagus burn was diagnosed. A value of $\mathrm{Hb}: 8.3 \mathrm{~g} / \mathrm{dl}$ was determined. One day later, the patient vomited fresh blood with a clot. Rectal inspection revealed melena. Hb was measured as $5.4 \mathrm{mg} / \mathrm{dl}$. While the patient was being prepared for a blood transfusion, his general condition failed, saturations dropped and he was intubated. Active bleeding was evident from the nasogastric tube. The infant did not respond to CPR and was declared dead.

In the autopsy performed, coagulated blood in the esophagus and trachea lumens was determined. It was observed that there was a burned area of $2 \times 1 \mathrm{~cm}$, located 5 $\mathrm{cm}$ below the epiglottis Fig 1 over the esophagus wall and an esophagotracheal fistula of $0.3 \mathrm{~cm}$ diameter was also observed passing Fig 2 through the trachea wall. Bleeding was determined in the small and large bowels. $150 \mathrm{cc}$ coagulated blood was observed inside the stomach.

No alcohol was found in the toxicology. No toxic substances were found except the active ingredients of metamizole and esomeprazole medicines at the treatment dosage.

In the histopathology report, tissue samples were seen to have the appearance of ulcers with wide areas covered by multi-layered flat epithelia over thinned sections of the esophagus and trachea and fibrovascular proliferation was observed over the entire esophagus wall and under the surface, with areas of fresh bleeding and necrosis moving through surrounding tissues. It was recorded that in-

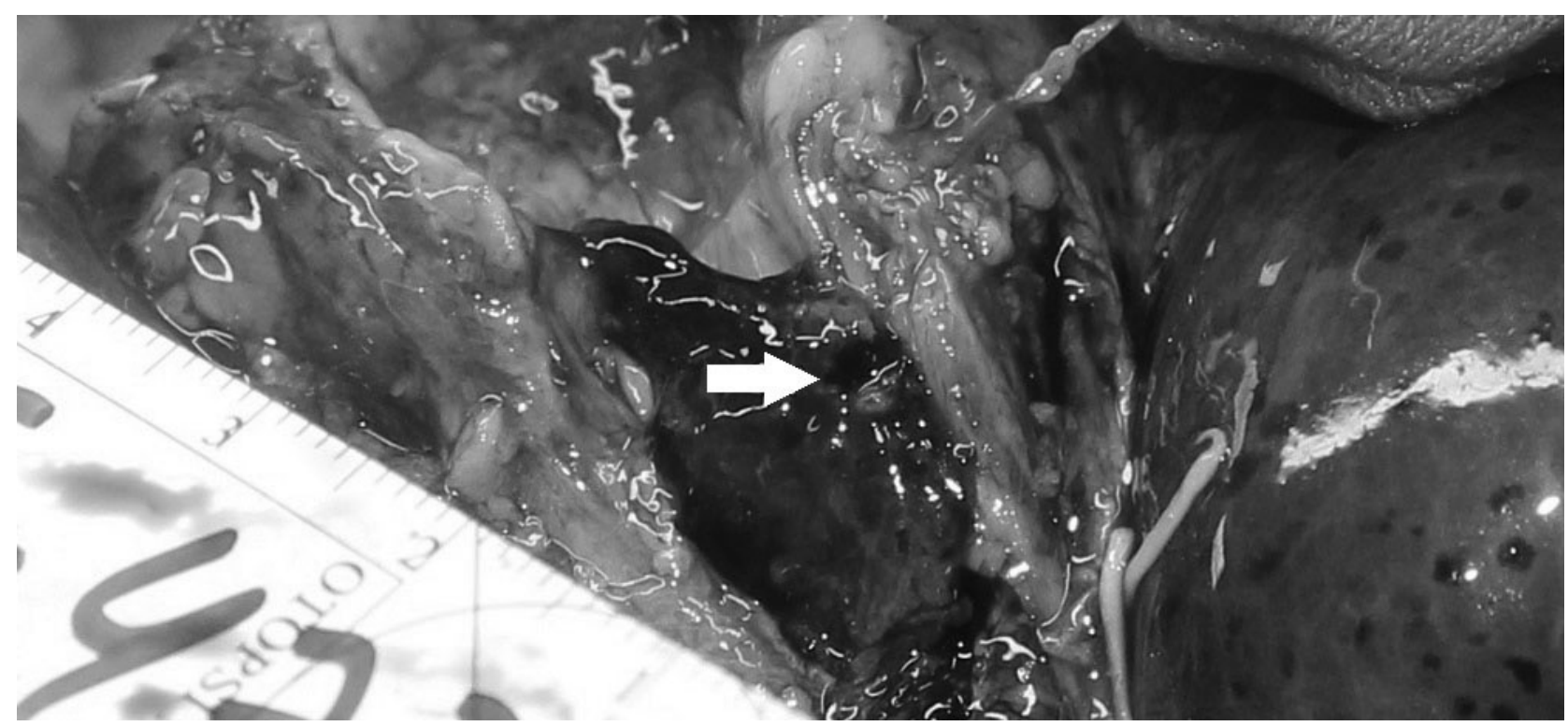

Fig 2. During the autopsy alkaline battery burn and perforation was detected in the esophagus. 
flammatory cell necrosis had reached and destroyed the trachea cartilage and had also passed through the trachea submucosa. Alveolar edema was recorded in the lungs, focal alveolar fresh bleeding areas and increased alveolar macrophages. Congestion and monocular urethritis cell infiltration forming aggregates with definite locally placed germinal centers under the epithelium were determined in tissue samples covered by columnar epithelial with goblet cells over thinned sections of the small and large bowels.

The cause of death was stated to be complications (esophagotracheal fistula, corrosive burn and gastrointestinal system bleeding) due to aspiration of a foreign substance (alkaline battery).

\section{Discussion}

In British literature, only 2 cases of deaths have been reported from 19 serious battery swallowing cases and in American literature of the last 3 years, there has only been 1 case (11-13). In literature, incidents have been reported at the highest rates between the ages of 6 and 12 years and are rarely seen in infants below the age of 1 year $(5,13)$. Distribution between the genders has been found to be equal (13). The case reported here was younger than 1 year old and male.

Foreign substances which have been left in the esophagus for a long period of time can form rare mediastinitis with or without abscess, esophagotracheal fistula, esophagovascular fistula, migration of the foreign substance out of the lumen, or fake esophagus diverticula due to perforation of the esophagus (14-17).

In a study of 2382 cases in America, serious complications of $0.35 \%$ of all cases were reported (5). In another study, in 4 of 8 cases a wrong diagnosis of lung infection was initially made (13). It has been emphasized that a delay in diagnosis causes more serious complications (13).

Differences in the chemical structure of the alkali battery may change the response given to the toxic effect. In some of the alkali battery samples mentioned in literature, th batteries contain manganese oxide, mercury, lithium, sodium hydroxide and zinc (13). Mercury oxide batteries are reported to be swallowed more often than other types and although mercury levels in the blood and urine increase, there may be no reported symptoms $(13,18)$. In the current case, heavy metal levels in the blood were not stated in the hospital records.

As the dimensions of an alkali battery increase, so the contact surface area increases, thus causing greater damage and toxicity and a long contact period will increase the toxic effect of the battery. In the current case, the contact period was considered long term as the battery was observed on radiography and removed three days after the vomiting complaint. Early diagnosis and timely ef- fective treatment are important factors to prevent latedeveloping complications.

\section{References}

1. Cihat Şarkış, Selçuk Yazıcı, Muhammet Can. Disk Battery Ingestion; A malpractice case that results in pneumonia. Adli Tıp Bülteni, 2016; 21(3): 196-198.

2. Yıldırım, M, Doğusoy, I, Okay, T, Yaşaroğlu, M, Demirbağ, H, Aydemir, B, Uncu İmamoğlu, O, Yıldırım, HN.Tracheabrochial Foreign Substances. Turkish Thoracic and Cardiovascular Surgery Journal. 2003;(11); 228-231.

3. İnci İ, Özçelik C, Ülkü R, Eren N. Esophagus Foreign Substances: 682 Inspection of Case. Thoracic and Cardiovascular Surgery Journal. 1999; (7); 148-152

4. Macpherson R.I, Hill J.G, Othersen H.B, Tagge EB, Smith C.D. Esophageal foreign bodies in children: Diagnosis, treatment and complications. AJR. 1996;(166); 919-924.

5. Litovitz T, Schmitz B.F. Ingestion of cylindrical and button batteries: an analysis of 2382 cases. Pediatrics. 1992;(89); 747-757.

6. Topçu S, Çetin G. Foreign substances of esophagus. In: Yüksel M, Başoğlu A, editors. Medical and Surgical treatment of esophagus illnesses. İstanbul: Bilmedya Grup; 2002; pp. 71-76.

7. Türkyılmaz A, Aydın Y, Genç F, Eroğlu A. Factor increasing swallowing of esophagus foreign substance for children: Alkali batteries. Turkish Thoracic and Cardiovascular Surgery Journal. 2008;16 (4), 250-253.

8. Kürkçüoğlu İ.C, Eroğlu A, Tekinbaş C, Karaoğlanoğlu N. Situation of swallowing alkali battery by accident for children. Turkish Thoracic and Cardiovascular Surgery Journal. 2003; (11); 193-194.

9. Maves M.D, Carithers J.S, Birck H.G. Esophageal burns secondary to disc battery ingestion. Ann Otol Rhinol Laryngol. 1984; (93); 364-369.

10. Willis G.A, Ho W.C. Perforation of Meckel's diverticulum by an alkaline hearing aid battery. Can Med Assoc J. 1982;(126); 497-498.

11. Blatnik D.S, Toohill R.J, Lehman R.H. Fatal Complication from an alkaline batterry foreign body in the esophagus. Ann Otol Rhinol Larygol. 1977; (86); 611-615

12. Shabino C.L, Feinberg A.N. Esophagial perforation secondary to alkaline battery ingestion. JACEP. 1978;(8); 360-362

13. Yardeni D, Yardeni H, Coran A.G, Golladay E.S. Severe esophageal damage due to button battery ingestion: can it be prevented?.Pediatr Surg Int. 2004;(20); 496-501

14. Nandi P, Ong G.B. Foreign body in the esophagus: review of 2394 cases. Br J Surg. 1978;(65); 5-9.

15. Newman D.E. Radiolucent esophageal foreign body; an often forgotten cause of respiratory symptoms. J Pediatr. 1978;(92); 60-63.

16. Remsen K, Lawson W, Biller H.F, Som M.L. Unusual prenestations of penetratign foreign bodies of the upper aerodigestive system. Ann Otol Rhinol Laryngol. 1983;(92); 32-44.

17. Yee K.F, Schild J.A, Hollinger P.H. Extramural foreign bodies (coins) in the food and air pasages. Ann Otol Rhinol Laryngol. 1975;(84); 619-623

18. Millar A.J.W, Rode H, Cywes S. Button-batery ingestions- a hazard of modern living. S Afr Med J. 1985;(68); 868-871. 